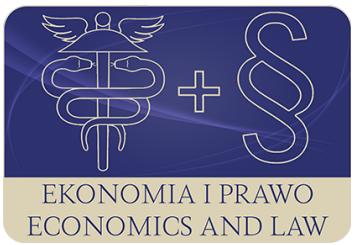

EKONOMIA I PRAWO. ECONOMICS AND LAW Volume 17, Issue 3, September 2018 p-ISSN 1898-2255, e-ISSN 2392-1625 www.economicsandlaw.pl

ORIGINAL ARTICLE received 02.01.2018; revised 04.05.2018; accepted 30.09.2018 Citation: Furmańska-Maruszak, A., \& Kamińska, K. (2018). Institutional and legal approach to eldercare versus sustainable work concept in selected European Union countries. Ekonomia i Prawo.

Ecomomics and Law, 17(3): 251-264. doi:10.12775/EiP.2018.018.

\title{
Institutional and legal approach to eldercare versus sustainable work concept in selected European Union countries
}

\section{AGNIESZKA FURMAŃSKA-MARUSZAK}

corresponding author

Nicolaus Copernicus University in Toruń, Institute of Sociology, Social Policy Unit, ul. Fosa Staromiejska la, 87-100 Toruń, Poland

$\square$ afmaruszak@umk.pl

\section{KATARZYNA KAMIŃSKA}

Warsaw School of Economics, World Economy Research Institute, German Economy Research Unit, Poland

๑kkamins@sgh.waw.pl

\begin{abstract}
Motivation: European societies face the problem of ageing populations and shrinking labour force. One of the ways to tackle this issue is the development of sustainable approach towards work. Sustainable work means creating such living and working conditions that they enable people to remain in employment throughout their extended working life. It requires gaining adequate skills, adjusting working conditions for elder workers' needs as well as helping them balance work and life. Family obligations are not only related to childcare but also to eldercare given to parents, step-parents or spouses. The balance between work and care might be supported both at the enterprise and the institutional level.

Aim: The article aims to examine the legal and institutional approach to care for the elderly in the selected EU countries (Germany, the UK, Finland and Poland) and to answer the question to what extent these institutions and laws support the concept of sustainable work.
\end{abstract}


Results: The extent to which national institutions and laws support sustainable work concept differ between countries, depending on the welfare model they represent. Finland represents Nordic welfare model in which publicly organised and financed eldercare is very generous, so sustainable work model is easy to put in practice. German welfare state also has its social policy well developed, and care systems are supported by the universal long-term care insurance. The UK is an example of a more liberal regime, in which sustainable work concept is more market-driven. Polish efforts to follow the German model with reference to social insurance are still under public debate. However, we doubt whether German solutions are possible to be introduced in Polish conditions due

to the different position of trade unions in this country, less importance of employee participation in company management than in Germany, and definitely less than in Germany the regulation of the labor market. In Poland, informal institutions, such as family and cultural customs, play a much greater role in organizing help in the care of an elderly person. Formal institutions play a smaller role in the organization of this care. We propose to take some solutions at the national and enterprise level to raise awareness of the need to take steps to address the issue of support for employees caring for an elderly person.

Keywords: sustainable work; social policy; long-term care insurance; eldercare JEL: D60; H53; J14; J22

\section{Introduction}

Demographic changes and the challenges that emerge in the European labour markets make eldercare an imminent welfare state policy issue (Hieda, 2012, p. 1). Apart from free play of market forces the state creates an institutional and legal framework for the functioning of economic order and creates conditions for citizens to develop and take actions to prevent social exclusion. Institutions that exist on the labour market are related to 'a system of laws, norms, or conventions resulting from a collective choice and providing constraints or incentives that alter individual choices over labour and pay'. Theses institutions affect individual decisions on the labour market. They are often (but not always) established by law and are 'the by-product of a political process' (Boeri \& van Ours, 2008, p. 3).

On the labour market, one of the most difficult moments in the employment process, one that can exclude from the job market for a certain period, is the situation in which employees undertake caring duties towards the elderly. Work-care balance is easier to be achieved when work of a carer is sustainable, which means working and living conditions are created in such a way that they 'support people in engaging and remaining in work throughout an extended working life’ (Eurofound, 2015, p. 2).

Sustainability of work may be supported by both public policies and company policies, especially human resources policy (Eurofound, 2016a, p. 6). In our study, we compare legal and institutional approaches to eldercare in four European countries with different welfare models (Germany, the UK, Finland and Poland) to examine the extent these methods make the work of carers sustainable. 


\section{Literature review}

The sustainable work concept emphasises the conditions that have to be met to help a person remain in work throughout his or her extended working life (Eurofound, 2015, p. 2). The reference literature presents typical life stages in which an employee experiences changes in role stressors, faces various challenges and is driven by different motives for working. Researchers usually focus on early and middle stages, distinguishing: a period of establishment (early career and family development), the stages when an individual focuses mainly on young children and career advancement and later stages characterised by an 'empty nest' syndrome (Thrasher et al., 2016, p. 3). The stages later than this 'empty nest' stage (when children become adults) are less frequently studied by scholars. The employees at these stages face the challenges related to their parents' or spouses' illness and other family changes. As a population ages, the life events seem to become more and more important for working life of an individual, mainly affecting women (Colombo et al., 2011, p. 86).

The life course perspective plays a significant role in the concept of sustainable work, emphasising that the situation of an employee on the labour market varies over time and is influenced by changes in his or her life, such as marriage, the birth of a child or starting a new job. It is also determined by one's health and various preferences and motives for working that might change over one's lifespan. Several critical transitions may take place in an individual's working life, such as school to work transition, parenthood, prime-age transitions related to employment risks, work to retirement and old age. 'Making work sustainable means organising jobs in a way that facilitates the adaptation of individuals to life-course transitions' (Eurofound, 2016a, p. 6).

The need to care for dependant family members tends to peak at the same time that the career (between the ages of 45 and 64) (Calvano, 2015, p. 163). It may affect prime-age transitions increasing the risk of unemployment or lower efficiency at work. This becomes a serious challenge both for public policies (e.g. labour market policy) and HRM policies in companies to make caregivers' work sustainable and help them to remain at work.

There are two main domains influencing the work and making it sustainable. The first domain is related to the characteristics of the job and work environments such as earnings, job prospects (e.g. job security, career), intrinsic job quality (physical and social environment, work intensity, autonomy) and working time (duration, flexibility). The second domain refers to the characteristics and the circumstances of an individual, such as care obligations, health and well-being, skills and employability, the employment experience (unemployment and inactivity) and motivation. Making work sustainable means making these two domains 'interact and complement each other in an ultimately positive relationship' (Eurofound, 2016a, p. 5). At the same time, both characteristics of the job and work environment, as well as characteristics and circumstances of the individual, are under the influence of various regulations, policies 
and practices at institutional, company and individual level (Eurofound, 2016a, p. 5). State and social partners and companies play a vital role in a sustainable work development.

In our study we focus on particular circumstances of an individual such as eldercare obligations and we analyse how the characteristics of the job and work environment are shaped by public policies. We take into account family policy (especially care arrangements and care-leave facilities) and regulations of working hours in four European countries.

In these countries the aforementioned institutions are tackled differently according to a welfare model adopted. We refer to the most popular classification of social policy. It is the division of regimes made by Gösta Esping-Andersen (1990), referring to two criteria: the type of social stratification and the degree of decomposition ${ }^{1}$. Esping-Andersen (1990) distinguished three regimes: the liberal, the conservative and the social-democratic one, in which decomposition is gradual, low, moderate, and high, respectively. In our study Finland is an example of the social-democratic model, Germany represents the corporatist model and the UK - the liberal model. We compare these models to the welfare model functioning in Poland. Poland is an example of a country that is hard to classify as one of the types of the welfare state mentioned above. The choice of a free market economy in 1989 was not followed by selecting a particular model of the welfare state.

\section{Methods}

In order to analyse the legal and institutional approach to eldercare, we analyse selected labour market institutions (care arrangements, regulation of working time and care-leave facilities), and check to what extent they support the carers in engaging and remaining in work.

When an employee faces a caring obligation, the access to care facilities constitutes an important determinant of his or her labour participation. Thus, we conducted a comparative analysis of long-term care system regimes and public coverage of long-term care (LTC) in Germany, the UK, Finland and Poland in order to examine care arrangements as a part of the family policy of a particular country.

Moreover, the sustainability of the carers' work might also be supported by creating adequate job prospects and the working time. Thus, we carry out a comparative analysis of the regulations of working hours and care-leave facili-

${ }^{1}$ Decomposition ('re-evolving') assumes that certain services are provided within the entitlement of the entities independent of market mechanisms, thus signifying the social exclusion of an individual from the market. Decomposition potential of social policies is related to three dimensions: the rules for access to specific benefits, the amount of compensation replacements and the scope of entitlements. If social rights are inviolable and available to all citizens irrespective of their efforts, this means the decommissioning of the status of an individual. 
ties in Germany, the UK, Finland and Poland, analysing the carers' entitlements and the level of coordination of long- term care systems.

\section{Eldercare arrangements in Germany, the UK, Finland and Poland}

When an employee faces care obligations, his or her labour participation is determined by the access to care services (in order to eliminate or weaken the substitution effect). Since fewer and fewer elder people live with their family members and more and more women are in paid work, families face more and more problems with meeting the care needs of the elderly. Thus, formal long term care services are required to support a family in their caring role (Hieda, 2012, p. 1).

Formal care can be understood as 'all care services provided in the context of formal employment regulations, such as through contracted services, by contracted paid care workers, declared to social security system' (Colombo at al. 2011, p. 11). Public policies aiming at fulfilling the care needs of the elderly are diverse across the countries (Hieda, 2012, p. 1), which reflects the way family policy is led in a particular country.

The extent of the care provided by the relatives varies between countries, depending on the context of public policy and the norms of filial obligations (Calvano, 2015, p. 164). The way formal long-term care is organised and financed depends on country-specific institutional features. Governments of European countries have different approaches to public long-term care coverage that mirror the way they perceive social protection in general. Taking into account the entitlements to long-term care benefits as well as the type of the coverage (whether it is a single or multiple programs) one can notice the differences between the four analysed countries (Colombo, 2012, pp. 24-35), see tablel.

Germany and Finland belong to the group of countries with universal coverage within a single programme, but the model of LTC financing is different. In Germany, LTC-dedicated insurance arrangements exist. They are separated from the health insurance and are mandatory. This way LTC coverage is comprehensive. So it is in Finland, but in this country, LTC services are universal and tax-funded. They are provided as a part of welfare and health care for the whole population. One of the key features of this country is great autonomy of local and regional authorities regarding the provision of services and funding for care and the right to tax. The eligibility for long-term care services is related to the municipality in which one lives. On the basis of an individual's needs assessment, the access to specific services is granted. In Finland, there is a wide range of physical and monetary benefits available for different purposes: childcare, care for the elderly, the disabled or the sick. The problem, however, is that the families who are in a particular situation cannot find the services they need most considering the available service packages. There are suggestions in this context that the network of services should be simplified and more transpar- 
ent for the residents. Instead of service packages, the employees should be able to choose and decide which service is really needed for a particular family (European Commission, 2016a, p. 4).

In the United Kingdom the arrangements for personal care are means-tested, but for severely disabled the benefits are provided regardless the contributions, the income or the taxes payable to the authorities. Social care is provided by the local governments and is funded both by the taxation and the user charges.

Poland belongs to the group of countries with a mixed system of the LTC coverage. There is universal access to cash allowances to cover the care cost, but they are scarce. The access to the social care is means-tested, and LTC within the health care is linked to the dependency level of a person treated. In Poland, unlike Germany, Finland and the UK, there is a legal obligation for the family to provide care for a dependant relative (Boele-Woelki et al., 2005, p. 127).

In Nordic countries the provision of formal care is high, and care is less likely to be provided by the family members. Thus, it does not affect their official labour market participation seriously. Public spending on long-term care (health and social components) in 2014 was highest in the Netherlands (4.3\% GDP) as well as in Nordic countries (Finland - 3.5\% GDP, Sweden - 3.2\% GDP, Denmark - 2.6\% GDP and Norway - 2.4\% GDP) (OECD, 2017).

In Finland, for example, family care is supported by different forms of cashfor-care schemes. In this area, we can distinguish formal and informal care support. Informal care support is a municipal system to entice someone in need of assistance to be treated in the carer's house. There is also a disability and care allowance for the pensioners, the disabled or the ill; a cash benefit paid out by the Social Insurance Institution (Kela). The care allowance is also payable to persons in institutional care. In recent years, the trend in LTC care has been highlighted in Finland, because this type of care is not such a burden on the budget as various forms of institutional care (European Commission, 2016a, p. 5).

The countries like Germany or the UK belong to so-called standard-care mix LTC regime (Lamura et al., 2007; Leichsenring et al., 2013, p. 21). The eldercare needs are met by formal as well as informal care. The government provides some standard of formal long-term care (medium provision), which is complemented by informal care (medium or low provision). In Germany and the UK, public spending on LTC equalled around 1\% of GDP (1.1\% for Germany and 1.2\% for the UK).

In Poland, like in other Southern and Eastern European countries, longterm care is more family-based. The provision of formal care is low, and public spending on long term care is much less than $1 \%$. The exception among the transition countries is the Czech Republic - 1.4\% GDP. In Poland and Hungary, the public spending on LTC equalled 0.3\% GDP.

The extent to which the carers' formal labour force participation is affected by the caring depends on the access to formal long-term care services and on the intensity of the care itself. It is also related to carer-friendly employ- 
ment such as flexible time schedules, leaves for the care or the ability to work part-time.

\section{Regulation of working hours in Germany, the UK, Finland and Poland}

The regulation of working hours institution is related both to the regulation of standard weekly working hours, and the potential barriers workers have to tackle when choosing a part-time instead of a full-time job (Boeri \& van Ours, 2008, p. 101).

Working time duration and organisation are regulated at different institutional levels across European countries, including state and statutory legislation, collective bargaining at the sectoral level, the negotiations at the company level, and individual negotiations between an employer and an employee (Eurofound, 2016b, p. 12).

Finland and Germany have negotiated working time setting regime. In this regime, the sectoral level is the most dominant institutional level. The role of social partners is decisive. They define the working standards within the framework of general statutory legislation (Eurofound, 2016b). This solution makes space for working hours adjustments, e.g. due to care. In Germany the Transport Workers Union (EVG) and railway company, Deutsche Bahn (DB) in 2016 introduced a new option for the employees to choose extra pay or extra time. They can choose between a pay rise, a reduction of working week by one hour per week or six additional days of holidays (the so-called 'EVG-Wahlmodell') (Eurofound 2017, p. 9).

In the UK, working time regulations are based on the individual level. The work duration and work organisation are in the majority set by the management of a company. The barraging structure is highly decentralised and reflects the unilateral working time regime (Eurofound, 2016b).

Poland belongs to the group of countries with pure mandated working time setting regime in which working time standards are defined by statutory legislation. Standard working time and work organisation are regulated by labour law.

In Poland, annual working time is the longest among the countries analysed (40 hours per week). In Germany, Finland and the UK the working time duration does not exceed 38 hours (table 2).

Moreover, in Poland, the combined total of agreed annual leave and public holidays is the shortest (29 days). In Germany, it equalled 37 days, in Finland 34 days and in the UK - 33 days (Eurofound, 2017, p. 26).

In Poland, collective agreements on working time duration are rare. Thus, the role of trade unions in demanding the more employee-friendly flexibility of working time is not as visible as in other analysed countries.

This flexibility is needed when the caring obligations towards dependant relatives appear. The right to request flexible working hours due to care varies between countries. 
In the UK, a working carer is entitled to request flexible working hours. Flexible working is related to the changes in hours of work, the times or place of work (European Commission, 2016d, p. 6). In order to receive the right to this, an employee must have work for over 26 weeks prior to the claim, must not have requested flexible work within 12 months prior to the claim and his/her dependent relative must be first-degree family (Colombo et al., 2011, p. 149). The right to flexible working can only be refused for clear business reasons.

In Poland, there are no special entitlements for the carers regarding working time arrangements. Their work-care balance might be supported by flexible working arrangements introduced in 2013: the extension of the reference period of the work settlement from 4 to 12 months and flexible working hours (opportunity to individually agree the time of starting and finishing their day of work) (European Commission, 2016c, p. 6).

In Germany, in 2008 came into force a legal entitlement to temporarily leave one's employment in order to care for a relative, The Home Care Leave Act (2008) (Gesetz über die Pflegezeit). It made possible:

- temporary absence: the introduction of entitlement to 10 days off work to care for a close relative;

- the care leave: the option of being released from work for a maximum period of six months.

The conditions of care leave were extended by the Family Care Leave Act (2011) (Familienpflegezeitgesetz), which introduced part-time care leave the employees are entitled to reduce their weekly working hours to as few as 15 hours for a maximum period of two years. Since January 2015 the employees have the right to take a family care period for up to 24 months (Act on Better Compatibility of Family, Care and Work, 2014) (Gesetz zur besseren Vereinbarkeit von Familie, Pflege und Beruf). During this time, the employees with care obligations may reduce their working hours to a minimum working time of 15 hours per week, if they care for a close family member requiring care at home. The loss of income can be made up for by an interest-free state loan. The voluntary granting by an employer of a care period for family members has thus become a binding obligation. The rule does not apply to businesses with 25 or fewer employees. Another important issue was the introduction end-of-life care leave: leave to accompany a close relative in the final phase of their life for up to three months (European Commission, 2016b, pp. 9-10).

In Finland, an employee can take advantage of flexible working arrangements. It has been possible as a part of the job alternation leave since 2010 . Those who decide to work part-time for caring reasons are eligible to a parttime allowance from the Employment and Economic Office. The compensation is proportional to the reduction of working hours (European Commission, 2016a, pp. 6-9). 


\section{Care leave facilities in Germany, the UK, Finland and Poland}

For carers, labour market participation and care decisions are determined by their preferences, working conditions, the situation on the labour market and also by family policies. Family policies (in case of employees with dependant relatives) consist of care leave facilities and care arrangements. Care leave arrangements make it easier for cares to participate in the labour market while providing care to their dependant relative (Boeri \& van Ours, 2008, p. 139).

In the UK the employees also have the right to time off due to emergency situations involving a dependent relative, including a breakdown in usual care arrangements, illness or death. The role of individual agreements is decisive. The length of a leave or whether it is paid or not is at the employer's discretion (European Commission, 2016d, p. 6).

In Poland, working family carers covered by sickness insurance are entitled to be paid leave up to 60 days per year to care for a sick child or another family member. During this time care allowance ( $80 \%$ of an average annual pay) is payable for the whole period (if the child is younger than 14) and for two weeks otherwise (European Commission, 2016c, p. 6).

In Germany, since 1 January 2015, in the event of an urgent emergency care situation, working family members may request a leave of absence from their employers of up to ten days. Since the beginning of 2015, they may claim an allowance in lieu of salary for this period (Pflegeunterstützungsgeld or care support allowance). As a general rule, such care support allowance amounts to $90 \%$ of the net income forfeited and is paid by the long-term care insurance. Also, it is currently already possible for employees to request a full or partial leave of absence up to six months to care for their family members (Pflegezeit or care period). Since the beginning of 2015, the carers are entitled to an interest-free state loan during the care period (European Commission, 2016b, pp. 9-10).

In Finland, there is a legally regulated possibility of taking job alternation leave. This kind of leave is available for 90 up to 359 days, but the carer should have been working for at least 12 months prior to the claim (and have at least ten years of experience). Since 2016 he/she also receives compensation of $70 \%$ of the daily unemployment allowance for a maximum of 180 days paid by the state through the unemployment funds and the Social Insurance Institution. To be eligible, one needs to have a 20-year-working history. The carers can also apply for unpaid leave. Its height relies on the collective agreements. There is no subjective right to the absence, only a recommendation. On request, an employee must present his or her employer a proof of the grounds for absence. (European Commission, 2016a, p. 5). 


\section{Conclusion}

Finland represents social-democratic model with comprehensive LTC public coverage based on taxes. Working time regime is set at sectoral level and carers are entitled to work part-time and receive part-time allowance. They are also entitled to paid and unpaid leaves for care. In German corporatist model public coverage of LTC is also comprehensive but based on public insurances. Like in Finland, negotiated working time regime gives more space for working hours adjustments when care duties appear. Carers are entitled to the reduction of working hours and their reduced income might be supported by interest-free state loan. They are also entitled to short paid and longer unpaid leaves for care.

In the UK, where liberal model exists, LTC public coverage is in majority means-tested. Working time regulations are based on the individual level. Carers can request flexible working hours and care leave but its conditions are at employer's discretion.

Poland is the only country among countries analysed above where there is a formal obligation for a family to care for a dependent relative. The family is the backbone of the whole long-term care system, but the support for working carers is not comprehensive. Formal care in institutions is more developed than home care. Universal allowances for people aged 75 and more are not sufficient to support family care. Working time is set by statutory legislation which makes less space for adjustments. Although flexible working arrangements were introduced in 2013 there are no special entitlements for carers. Paid leave for care is possible and paid for maximum 14 days. It is not possible to take longer unpaid leave for care.

The implementation of the concept of sustainable work requires the state's involvement in family policy and the labor market by introducing regulations enabling the employee to remain in employment and allow him/her to take care of the elderly. Such regulations are found in countries where the role of the state in the economy is significant. An example of this are the Scandinavian countries and Germany. It is also important to note the important role that trade unions play in the regulation of these countries

The institutions analysed above (care arrangements, regulations of working time and care leave facilities) differ according to the level of coordination, scope and financing regimes and the extent to which they put in practice sustainable work concept allowing carers to stay in employment as long as possible.

The regulation of state-level care in Finland and in Germany provides support the concept of sustainable work. In Finland publicly organised and financed eldercare is generous, so sustainable work model is easy to put in practice, but its maintenance affects the state of public finances. In 2016, the state debt to GDP in Finland was $63.6 \%$. That is why Finland is promoting the non-institutional LTC solutions. It results in a slow shift of the duty of care from the state to the family. German welfare state also has a well-developed social policy and care systems are supported by the universal long-term care insurance. The 
legal changes that occur in the family policy of German law extend the opportunities and the entitlements of employees who are in a situation of needing to combine their professional duties with the care of an older person.

Moreover, decentralization of working time setting might be also favourable to sustainable work model especially when social partners are strong and able to negotiate carers-friendly employment conditions. When working time regulation are based on individual (UK) or sectoral level (Germany, Finland), there is more place for adjustments.

Income loss due to part-time work or care leave is compensated to the greatest extend in Finland. Germany gives the option of interest-free state loans while in the UK it is more the case of individual bargaining.

It is difficult to indicate which solutions from the countries analyzed by us are possible for direct implementation in Poland. For many reasons, the model closest to Poland is the German model. However, unlike Germany, in Poland the role of trade unions and the degree of labor market regulation is much smaller. Poland should look for its own solutions. The family policy and supporting social initiatives have a huge role in this respect. The state should take measures to strengthen the role of trade unions and their participation in the co-decision process in specific sectors of the economy and in the field of legislative initiatives. In addition, it is worth undertaking initiatives aimed at increasing the awareness of Polish employers about the need to support employees at a time when they need to care for an elderly person and thus gradually introduce a new approach to human resources management policy in enterprises. An important issue that should be solved at the state policy level is to allow the employee to take leave for the time of caring for an elderly person and to make work time more flexible. At the moment, however in Poland there is an option for state allowance but only when a carer withdraws from the labour market. There is a need to recognize working carers and make more space for work-care adjustments.

\section{References}

Boele-Woelki, K., Braat, B., Curry-Sumner, I. (Eds.). (2005). European family law in action. Volume III: parental responsibilities. Retrieved 28.08.2017 from http://intersentia.com.

Boeri, T., \& van Ours, J. (2008). The economics of imperfect labour markets. Princeton: Princeton University Press.

Cabrita, J. (2017). Developments in working time 2015-2016. Retrieved 28.08.2017 from https://www.eurofound.europa.eu.

Calvano, L. (2015). Balancing eldercare and work. In R.J. Burke, C.L. Cooper, \& A.G. Antoniou (Eds.), The multigenerational and aging workforce. Challenges and opportunities. Cheltenham-Northhampton: Edward Elgar Publishing. 
Colombo, F. (2012). Typology of public coverage for long-term care in OECD Countries. In J. Costa-Font, \& C. Courbage (Eds.), Financing long-term care in Europe. Institutions, markets and models. Palgrave Macmillan: London. doi:10.1057/9780230349193.

Colombo, F., Llena-Nozali, A., Mercier, J., \& Tjadens, F. (2011). Help wanted? Providing and paying for long-term care. Paris: OECD Publishing. doi:10.1787/9789264097759-en.

Esping-Andersen, G. (1990). The three worlds of welfare capitalism. PrincetonNew Jersey: Princeton University Press.

Eurofound. (2015). Sustainable work over the life course: concept paper. Luxembourg: Publications Office of the European Union. doi:10.2806/281708.

Eurofound. (2016a). Sustainable work throughout the life course: national policies and strategies. Luxembourg: Publications Office of the European Union. doi:10.2806/874170.

Eurofound. (2016b). Working time developments in the 21st century: work duration and its regulation in the EU. Luxembourg: Publications Office of the European Union. doi:10.2806/947659.

Eurofound. (2017). Developments in working time 2015-2016. Luxembourg: Publications Office of the European Union. doi:10.2806/958139.

European Commission. (2016a). ESPN thematic report on work-life balance measures for persons of working age with dependent relatives: Finland. Retrieved 28.08.2017 from http://ec.europa.eu.

European Commission. (2016b). ESPN thematic report on work-life balance measures for persons of working age with dependent relatives: Germany. Retrieved 28.08.2017 from http://ec.europa.eu.

European Commission. (2016c). ESPN thematic report on work-life balance measures for persons of working age with dependent relatives: Poland. Retrieved 28.08.2017 from http://ec.europa.eu.

European Commission. (2016d). ESPN thematic report on work-life balance measures for persons of working age with dependent relatives: UK. Retrieved 28.08.2017 from http://ec.europa.eu.

Familienpflegezeitgesetz vom 6. Dezember 2011 [The Family Care Leave Act of 11 December 2011] (BGBl. I S. 2564) (Germany).

Gesetz über die Pflegezeit vom 28. Mai 2008 [The Home Care Leave Act of 28 May 2008] (BGBl. I S. 874, 896) (Germany).

Gesetz zur besseren Vereinbarkeit von Familie, Pflege und Beruf vom 23. Dezember 2014 [Act on Better Compatibility of Family, Care and Work of 23 December 2014] (BGBl.I S.2462) (Germany).

Hieda, T. (2012). Political institutions and elderly care policy. Comparative politics of long-term care in advanced democracies. London: Palgrave Macmillan.

Lamura, G., Mnich, E., Nien, B., Krevers, B., McKee, K., Mestheneos, E., \& Dohner, H. (2007). Dimensions of future social service provision in the ageing societies of Europe. Advances of Gerontology, 20(3). 
Leichsenring, K., Billings, J., \& Nies, H. (Eds.). (2013). Long-term care in Europe. Improving policy and practice. London: Palgrave Macmillan. doi:10.1057/9781137032348.

OECD. (2017). Long-term care. Retrieved 28.08.2017 from http://www.oecd. org.

Thrasher, G.R., Zabel, K., Wynne, K., \& Baltes, B.B. (2016). The importance of workplace motived in understanding work-family issues for older workers. Working, Ageing and Retirement, 2(1). doi:10.1093/workar/wav021.

\section{Acknowledgements}

Author contributions: authors have given an approval to the final version of the article. Authors contributed to this work equally.

Funding: this research was fully funded by the authors.

Note: the results of this study were presented at 9th International Conference on Applied Economics Contemporary Issues in Economy (June 22-23, Torun, Poland). 


\section{Appendix}

Table 1.

Public LTC coverage in Finland, Germany, UK and Poland

\begin{tabular}{llcc}
\hline \multicolumn{1}{c}{ Country } & \multicolumn{1}{c}{ Universal coverage } & $\begin{array}{c}\text { Legal family } \\
\text { obligations to care }\end{array}$ & $\begin{array}{c}\text { Public spending on LTC } \\
\text { (in \% GDP in 2014) }\end{array}$ \\
\hline Finland & yes, tax-funded & no & high (3.5\%) \\
Germany & yes, public insurance & no & medium (1.0\%) \\
United Kingdom & no, means-tested & no & medium (1.2\%) \\
Poland & partly (universal cash allowances, & yes & low (0.3\%) \\
& means-tested for social care) & & \\
\hline
\end{tabular}

Source: Boele-Woelki et al. (2005); Colombo (2012); OECD (2017).

Table 2.

Working time setting regimes and average collectively agreed normal annual working hours in 2016 in Finland, Germany, UK and Poland

\begin{tabular}{|c|c|c|c|c|c|c|c|}
\hline \multirow[t]{2}{*}{ Country } & \multirow[t]{2}{*}{$\begin{array}{c}\text { Level } \\
\text { of regulation }\end{array}$} & $\begin{array}{l}\text { Weekly } \\
\text { hours }\end{array}$ & $\begin{array}{c}\text { Gross } \\
\text { annual hours } \\
\left(A^{*} 52\right)\end{array}$ & $\begin{array}{l}\text { Annual leave } \\
\text { (in days) }\end{array}$ & $\begin{array}{c}\text { Public } \\
\text { holidays } \\
\text { (in days)* }^{*}\end{array}$ & $\begin{array}{c}\text { All leave } \\
(\mathrm{C}+\mathrm{D}) \\
\text { (in hours) }\end{array}$ & $\begin{array}{c}\text { Annual } \\
\text { hours } \\
(B-E)\end{array}$ \\
\hline & & $\mathrm{A}$ & B & C & $\mathrm{D}$ & $E$ & $\mathrm{~F}$ \\
\hline Finland & sectoral & 37.5 & $1,950.0$ & 25.0 & 9.0 & 255.0 & $1,695.0$ \\
\hline Germany & sectoral & 37.7 & $1,960.4$ & 30.0 & 7.0 & 279.0 & $1,681.4$ \\
\hline $\begin{array}{l}\text { United } \\
\text { Kingdom }\end{array}$ & $\begin{array}{l}\text { individual } \\
\text { (company) }\end{array}$ & 37.0 & $1,924.0$ & 25.0 & 8.0 & 244.2 & $1,679.8$ \\
\hline Poland & $\begin{array}{l}\text { central } \\
\text { (state) }\end{array}$ & 40.0 & $2,080.0$ & $20.0^{*}$ & 9.0 & 232.0 & $1,848.0$ \\
\hline EU-28 & - & 38.0 & $1,976.6$ & 24.6 & 9.2 & 257.1 & $1,719.5$ \\
\hline
\end{tabular}

Note:

* — statutory minimum paid annual leave.

Source: Cabrita (2017, p. 26); Eurofound (2016b). 